\title{
WESTERN MILITARY CULTURE AND COUNTERINSURGENCY: AN AMBIGUOUS REALITY
}

\author{
Martijn Kitzen \\ Netherlands Defence Academy, Department Military \\ Operational Art and Science
}

With 2000 years of examples behind us we have no excuse, when fighting, for not fighting well ...

TE Lawrence in a letter to BH Liddell Hart ${ }^{1}$

\begin{abstract}
Contemporary campaigns in Iraq and Afghanistan once again have demonstrated that conventional armies experience many problems in adapting to counterinsurgency operations. This article seeks an explanation for those problems by exploring the conceptual background of both Western-style conventional armies and counterinsurgency. In essence, Western military culture is about fighting largescale decisive battles with armies of other states. This contrasts strongly with counterinsurgency, which is about outbidding the insurgents for the favour of the people with a minimised use of force. The article analyses the further consequences of this conceptual clash between Western military culture and counterinsurgency in the reality of counterinsurgency warfare. It is explained that the contrast between both concepts leads to an ambiguous reality in which soldiers are aware of the specifics of counterinsurgency theory, but refer back to Western military culture for fighting counterinsurgency campaigns.
\end{abstract}

\section{Introduction}

In 1933, TE Lawrence wrote to his friend Basil Liddell Hart to stress the importance of military history for the education and development of officers.

Scientia Militaria, South African Journal of Military Studies, Vol 40, Nr 1, 2012, pp. 1-24. doi: $10.5787 / 40-1-982$
Western military culture, the shared vision on organisation and the use of armed forces based on Western concepts, and these historic experiences are inherently bracketed together. Conflicts are traditionally fought by regular 
armies seeking to defeat their enemy on the battlefield. This has culminated in the $20^{\text {th }}$-century paradigm of interstate industrial warfare. Technological inventions and the idea of "nation-in-arms" led to large-scale battles with massive use of force, as was clearly the case in both world wars. The arrival of nuclear weapons at the end of the Second World War eventually led to a strategic stalemate. The underlying concept of industrial warfare, however, remained unchanged.

Contemporary Western military culture stems from this background. Thus, the preferred focus of Western armed forces is the fight against similar opponents: adversaries with equal weapons and goals. Battles, however, are no longer exclusively fought on a battlefield bound by geographic borders, nor are the involved parties necessarily armed forces. After the end of the Cold War, a shift occurred in international security. The contemporary situation is characterised by the emergence of non-state adversaries, who are capable of confronting Western states with a threat both abroad and within their homeland societies. Civilians fulfil a dominant role in the new situation. Rupert Smith refers to the new paradigm as "war amongst the people: Civilians are the targets, objectives to be won, as much as an opposing force". ${ }^{2}$ Western states have to counter enemies who have the ability to emerge from and submerge in civil societies around the world.

The military consequence of this paradigm change is that Western soldiers are fighting irregular enemies in foreign societies, as is the case in Iraq and Afghanistan. These adversaries are supported by local people and are capable of delivering force to effect. They choose not to fight large-scale battles against Western forces, but rather use messy tactical tricks, which enable them to fight a battle on their conditions. An improvised explosive device, for instance, can be a weapon of choice, enabling them to kill Western soldiers or civilians without exposure to abundant Western military force. When sensing an advantageous situation, insurgents may decide to launch a direct attack on, for example, an undermanned outpost. The "modern" military art used to fight such an irregular enemy is known as counterinsurgency. Counterinsurgency is part of the broader concept of irregular warfare, which harks back to the same ancient times as the notion of traditional Western military art. Throughout history there have been many cases which render the insight that, when fighting irregulars, conventional armed forces are faced with problems more difficult to overcome than those experienced during campaigns against similar adversaries. In spite of historic examples, Western armed forces are still experiencing major troubles in contemporary counterinsurgency campaigns. 
Lawrence argues that there is no excuse for not fighting well as history has provided us with the necessary examples. This article, however, argues that such an excuse does exist. It can be provided by the predominant way in which Western forces regard themselves; Western military culture is about operations against conventional forces. Today's armed forces are still fitted for large-scale battles visà-vis similar opponents, while they in reality are mainly facing insurgencies. The proposition of this article therefore is provided by the antithesis of Western military culture and counterinsurgency. I argue that this antithesis is the culprit for many problems experienced in contemporary counter-insurgency campaigns. The differences between Western military culture and counterinsurgency will provide a thorough insight into the practical consequences of the theoretical clash of both concepts. However, in order to identify those differences, Western military culture and counterinsurgency first have to be discussed separately.

\section{Western military culture}

The study of culture as a determinant of the nature of warfare explains differences between armies in their approach to common problems battle has brought them. Military culture is about how armies think about themselves and about the conceptions of war and combat within a military. ${ }^{3}$ Although military culture can be used to explain the unique character of a nation's armed forces, it also provides the insight that Western armed forces share an elementary view on the use and conduct of their means. Western military culture, as referred to in this article, constitutes the shared conceptions of war and combat of armed forces that are organised and fought according to concepts that originated in Western countries. The so-called Western way of war is characterised by a deeply rooted preference for large-scale battles using massive force. ${ }^{4}$ According to well-known military historian John Keegan, Western military culture comprises three elements: moral, intellectual and technological. ${ }^{5}$ Just like other scholars, such as Victor Hanson, Keegan dates the start of the development of Western military culture 2500 years ago in classic Greece. Although the existence of an evolutionary line from ancient times until our age is questionable, the pitched battles between phalanxes of hoplites clearly illustrate the moral essence of Western military culture:

It is this Western desire, for a single, magnificent collision of infantry, for brutal killing with edged weapons on a battlefield between free men, that has baffled and terrified our adversaries from the non-Western world for more than 2500 years. ${ }^{6}$ 
Classical Greek warfare was based on decisive battle fought by rigid infantry formations on a custom-picked piece of flat ground. ${ }^{7}$ The outcome of such a battle was accepted by all involved parties and therefore the end of the battle meant the end of the conflict. The key feature of classical Greek warfare was the active pursuit of a quick and decisive outcome. This led to an attitude in which it was morally imperative to actively seek battle in order to enforce a result. The end of a battle meant that society could return to normal life as the outcome of the fight was accepted by all parties. The moral element of Western military culture clearly shows itself in the attitude of the active pursuit of deadly confrontation with the enemy in order to enforce decisive battle. In our times, this is also the main character of the moral component. According to Keegan, the medieval people who inhabited postRoman Europe took over the Greek attitude of active pursuit of decisive face-to-face battle (via the Roman Empire, whose forces adopted the Greek methods), thus forming an evolutionary link between classic and modern ages. ${ }^{8}$ Hanson also assumes such a transfer of the moral component of Western military culture. Most scholars, however, criticise such a continuum. ${ }^{9}$ According to Lynn, medieval and early-modern armies were more likely to avoid battle than to seek it. ${ }^{10}$ Those battles that were fought were all but decisive. Sieges were the predominant form of warfare and wars were mostly protracted by nature. The decisive battle-seeking moral element of Western military culture only returned with Napoleonic warfare.

The intellectual and technological dimensions of Western military culture stem from respectively the crusades and the $18^{\text {th }}$ century. ${ }^{11}$ Although there is no continuum for the moral of decisive face-to-face battle between Roman and modern European Warfare, it cannot be denied that during this period, those other two elements of Western military culture came into sight. The intellectual dimension of warfare was introduced as a result of the crusades. The encounter with the Islamic concept of Jihad or holy war finally brought a solution for the Christian dilemma over the religious legitimacy of war making. The adoption of the idea of holy war by the crusaders embedded war in a framework that would thereafter evolve along intellectual and ideological lines. Although Western soldiers had enjoyed the benefits of technological developments throughout time, the introduction of wieldy gunpowder weapons gave them a real advantage. Although gunpowder weapons were invented and used earlier by the Chinese, it was the European armies which exploited the full potential and perfected the use of such weapons in the $18^{\text {th }}$ century. Thus, this available technology was massively used from the $18^{\text {th }}$ century onwards.

When Napoleon reintroduced decisive battles to enforce a quick outcome in a conflict, he could therefore take advantage of all elements of Western military 
culture: moral, intellectual and technological. Napoleonic warfare "threw armies of unprecedented size on country-smashing campaigns of conquest through decisive manoeuvres, and usually, battle". ${ }^{12}$ This kind of warfare aimed at the destruction of the enemy's main force in a decisive battle between mass armies and was made possible by the concept of levée en masse. This concept granted the Grande Armée a continuous source of conscript manpower. In this way, Napoleon introduced the ideological element of total warfare by using mass armies and thus mobilising the society for the conduct of war. Napoleonic warfare was also characterised by the use of mobile firepower and other new technologies, including balloons and the semaphore telegraph. ${ }^{13}$

The theoretic principles of Napoleonic warfare were canonised by a contemporary Prussian soldier, Carl von Clausewitz. Although his writings also discussed practical and theoretical aspects of so-called small wars, his work, and especially his magnum opus, Vom Kriege, would have a profound impact on the development of Western military culture with its preference for conventional warfare. $^{14}$ Total industrial warfare, as culminated in the two $20^{\text {th }}$-century world wars, evolved from $19^{\text {th }}$-century concepts and the availability of new technologies. It was Von Clausewitz's work which provided the theoretic guidance for this development. Especially three principles founded the conceptual base for industrial warfare: the trinity of the state, the army and the people, the primacy of policy and finally the description of war as a product of both strength and will. ${ }^{15}$ The Clausewitzian trinity was a consequence of the massive character of the Napoleonic war. In order to mobilise the full resources of the State, it was essential that the three equal components of the trinity were kept in balance. The primacy of policy comprehends the fact that war stems from a political objective. Therefore, war should be waged in accordance with the political motivation which started it. By defeating an opponent on the battlefield, the state could show its superior strength. This affects the will of the enemy state to continue the war. A defeat of the adversary's main force leads to the collapse of the enemy's will, resulting in victory. Thus, decisive battles between massive armies were essential to enforce an outcome to war. In order to wage these kinds of wars, the state needed the people and the military. Therefore, the political decision to go to war could only be taken when the relation between state, people and the military was balanced.

The gruesome outcomes of the deadly combination of decisive face-to-face battle, the concept of total war, and $20^{\text {th }}$-century technology are well known. The quest for more and better firepower has never stopped. The development of nuclear weapons during the Second World War was a logical outcome of this process. The 
nuclear bomb, however, had more impact on warfare than any other newly invented weapon in history. The nuclear arms race between the United States and the SovietUnion led to a situation of mutual assured destruction. The threat of such a catastrophe alone was enough to prevent the outbreak of a nuclear war as each state - i.e. each involved Clausewitzian trinity - would have been destroyed completely. What was the effect on Western military culture? The nuclear stalemate did not eliminate the concept of conventional large-scale battle. Actually, conventional forces were the only tool of force which could engage in battle without destroying the world. ${ }^{16}$ This resulted in the strategic doctrine of flexible response: conventional forces were to be deployed - without the support of nuclear weapons - as a reaction to a perceived threat; thus, not provoking nuclear war. For the better part of the $20^{\text {th }}$ century, Western armies kept on thinking about, training for and (sometimes) fighting the same decisive battles with massive (non-nuclear) firepower as were fought during both World Wars. Therefore, the paradigm of interstate industrial war firmly took root in contemporary Western military culture.

After the Cold War had ended, Western countries fought a major conventional battle against Iraq. This fight, however, did not set the stage for the future. Western armies became heavily entangled in the murky business of peacekeeping during the 1990s. From the streets of Mogadishu to the hilly countryside of Bosnia, Western soldiers were facing enemies who did not fight according the notion of Western military culture. Battles were no longer fought on the battlefield, neither were all the involved parties armed forces, or did they form part of a classical Clausewitzian trinity of state, army, and people. Thus, the conflicts of the 1990 s ushered what Rupert Smith has called a paradigm shift from interstate industrial war to war amongst the people as the predominant form of warfare encountered and fought by Western forces. Western military culture, however, remained true to its principle of decisive large-scale battle. The development of industrial total warfare had led to a rigid attitude towards conflicts of another nature. This is not surprising. Western armies had also fought so-called low intensity conflicts during the Cold War. In Vietnam, for example, first France and later the United States were completely preoccupied by the Western military culture of industrial warfare. French and American forces sought confrontation with Vietminh or Vietcong units to enforce a decision. Modern technology and mass firepower were used to disappointing effect against an enemy who fought with much simpler means and who preferred to avoid battle. ${ }^{17}$

One French officer even compared French actions with Don Quixote's fight against the windmills, the only difference being that the French were fully aware of 
the fact that they were attacking windmills instead of giants. ${ }^{18}$ According to Smith, even the successful counterinsurgency campaign during the Malayan emergency was fought by soldiers whose mindset was completely directed on industrial warfare. ${ }^{19}$ British soldiers were successful due to the fact they were spread over the country. This did not allow them to concentrate on a decisive battle; instead, they undertook local efforts in close coordination with other government agencies. Thus, the circumstances in Malaya forced the British to adapt their way of fighting. The need for such an adaptation to properly conduct counterinsurgency campaigns illustrates that industrial Western military culture negatively influenced the ability to wage these unconventional "hot engagements" during the Cold War. This preference for decisive large-scale battles and technology remained with Western soldiers after the Cold War, and its principles still dominate Western military operations. In Smith's words:

This underpinning became a doctrine which then devolved into a dogma, 2an unquestionable fact, which solidified the enduring appeal of interstate industrial war long after its demise, and indeed in many ways to this day. For at the root of many of the problems we have now with the use of force and forces is their persistent structuring and use as if the old paradigm still held ... ${ }^{20}$

Thus, the preference for large-scale decisive battle with technological advanced equipment remains the main feature of Western military culture. Western warfare, however, has experienced some change. To understand this, we have to look at the very reason which bellies warfare: the political objective. Traditionally, Western countries waged war for the sake of national interest. Whenever the (perceived) threat was large enough, the state would firmly defend its interest. In today's conflicts, however, war is increasingly removed from immediate interest. ${ }^{21}$ Wars are fought far from home for the sake of regional influence. Sometimes there even appears to be no relevance with national interest. Humanitarian interventions under influence of public opinion are an example of such conflicts.

As a result of this lack of direct interest, the will to engage in deadly conflict is affected. War has become about limiting risks. Contemporary wars have become "risk-transfer wars". 22 A significant trait of these kinds of wars is to avoid casualties among friendly soldiers and civilian non-combatants. In order to minimise political risk, governments seek to offer their soldiers the best available protection. This, however, often contradicts with the ambition to limit civil casualties. ${ }^{23}$ Western states prioritise their soldiers' lives above those of civilians. ${ }^{24}$ How does this effect 
Western military culture? Massive firepower and technology are once again emphasised. Dutch soldiers deployed to Southern Afghanistan from 2006 until 2010, for example, could count on an unprecedented amount of artillery and air support for their force protection. In order to give their troops better protection the Dutch government even hastily acquired better armoured Bushmaster vehicles. Technology and firepower have also become more important in contemporary conflict. The question that is raised is how all this relates to the effective execution of a counterinsurgency campaign. In order to answer this question, let us first focus on counterinsurgency.

\section{Counterinsurgency}

What is counterinsurgency? The word obviously pertains to the reaction towards an insurgency. So, in order to obtain an enhanced understanding of counterinsurgency, let us first answer the underlying question: what is insurgency? In the contemporary discourse on military operations, terms like "terrorism", "subversion", "guerrilla" and "insurgency" are often used as synonyms. Although there are similarities, there also are profound differences between these terms. "Subversion" refers to non-violent activities in order to create a network of underground support for an uprising. Thus, subversion is about winning the support of the people, in which communication is the main asset. Guerrilla fighting is a form of warfare which can support regular armies as much as it can be used by insurgents. "Terrorism" is a generic term, which refers to violent actions to influence political behaviour. Counterinsurgency expert Thomas Mockaitis defines insurgency as "a hybrid form of conflict that combines subversion, guerrilla warfare, and terrorism. It is an internal struggle in which a disaffected group seeks to gain control of a nation". ${ }^{25}$ Insurgents might therefore use the methods of subversion, guerrilla and terrorist tactics in order to establish political control over (parts of) a country.

Insurgencies furthermore combine different methods in order to obtain a political goal. The first aim of insurgency is to widen its support base. With subversive methods, the insurgents seek to convince local people that they are offering better perspectives than the existing government does. In this way, a country might even be out-administered. ${ }^{26}$ The supportive base the insurgents pursue will generate additional military capabilities. Mao's dictum that a guerrilla should rely on the local population "like fish swimming in the water of the population" thus certainly also applies to insurgencies. During the protracted period an insurgency is likely to endure, the activities to encourage local support have to continue as they are essential to the insurgency's persistence. An example is provided by the Fuerzas 
Armadas Revolucionarias de Columbia (FARC). Since its establishment in 1966, the FARC grew from 350 fighters to approximately 20000 militant insurgents in the year $2000 .{ }^{27}$ During the first years of its existence, the FARC had a hard time subverting the allegiance of the local population. It finally managed to persuade local farmers in isolated coca-growing regions that they would be better off with the FARC than with the Columbian government. This led to an explosive growth, and today the FARC insurgency is still considered a serious threat to Columbia's security.

Parallel to the obtainment of the people's support, insurgents will attack government targets (both military and political). They will use guerrilla tactics in order to fight on conditions that are advantageous to them, as described in the introduction. Provoking government forces to overreact can be part of the insurgents' strategy. The use of extreme violence in such a reaction can further diminish popular support to the government's cause. After an action, the insurgents merge into the population or retreat to an inaccessible hideout. Thus, insurgents are extremely hard to catch. They can live to fight another day.

Terrorism can be another weapon of choice in the insurgent's hands. It can be directed either at government targets or at the general population. ${ }^{28}$ The military effect of terrorist actions is very limited; it is the psychological dimension terrorism seeks to influence. Terrorism can demonstrate the government's inability to provide security. In the case of attacks on the larger population, terrorism is used either to prevent collaboration with government authorities or to force people to comply with insurgent demands. The indiscriminate nature of a terrorist attack is both its strength and its vulnerability. If the insurgents perpetrate terrorist attacks too often, it can affect their support in a negative manner.

Operations mounted by Taliban insurgents in Afghanistan offer some illustrations of insurgents' use of violent methods. Foreign aid workers, for instance, are a legitimate target for insurgents. Hijacking and targeted killings are among the tactics used to scare away those people, who assist the Afghan government by their contribution to the reconstruction effort. Attacks against isolated outposts by a superior insurgent force occur regularly. Whenever insurgents are convinced they are in an advantageous situation, large brutal attacks may take place. In October 2007, massive insurgent actions around the Dutch base in Deh Rawood (Uruzgan Province) forced NATO to reinforce the small garrison by sending in extra Dutch infantry and British Ghurkhas. Patrols were continuously harassed by Taliban attacks and freedom of movement for ISAF (International Security Assistance 
Force) forces around Deh Rawood almost ceased to exist. On 27 January 2004, a Taliban insurgent equipped with a suicide-vest hanged with mortar and artillery rounds, managed to blow himself up in the middle of a NATO convoy. Ever since, terrorist-style suicide attacks have returned regularly as a Taliban tactic against NATO soldiers and Afghan government officials. ${ }^{29}$

Counterinsurgents want to refuse insurgents their objectives. As an insurgency heavily depends on popular support, the local population is the key to a successful counterinsurgency campaign. By identifying the causes which convince people to support the insurgency, the government can contribute towards the needs of the people. Counterinsurgency thus is all about contrasts: it is about outbidding the insurgents for the loyalty of the people. ${ }^{30}$ The use of force against insurgents is also an essential part of counterinsurgency. Indiscriminate violence, however, might harm the counterinsurgents' objectives beyond the amount of damage it causes to the insurgents. This can be illustrated by the following example. In June and July 2004, the United States mounted a series of precision air attack against suspected Al-Zarqawi safe houses in Fallujah. ${ }^{31}$ Although the inhabitants were warned by pamphlets, a total of 84 civilians were killed by heavy bombs or missiles. There were no insurgent combatants counted amongst the casualties. The inhabitants' support for the new Iraqi government and its American allies further diminished, thereby creating a permissive environment for the establishment of an insurgent sanctuary. Counterinsurgents should therefore show restraint with regard to the use of force: "dead insurgents are a bonus and not a reliable indicator for success in winning the support or acquiescence of the people". 32 Only when the enemy is clearly identified should violence be unleashed. However, in order to defeat the insurgency, brute force alone certainly will not suffice. Instead of an indiscriminate use of force, a counterinsurgency campaign should provide support to an insurgency-threatened government by the deployment of a range of military, political and socio-economic measures. ${ }^{33}$

Counterinsurgency theory stresses the aforementioned approach. This method resembles the indirect approach to conventional military operations. Instead of fighting the opponent head-on in a fierce clash, the indirect approach seeks to hit the enemy by attacking vulnerable essential assets. In a similar way, counterinsurgency pursues effect by depriving the enemy of his vital popular support. Counterinsurgency harks back to $19^{\text {th }}$-century colonial warfare. During the expansion of colonial empires, Western armies often came across indigenous resistance. At first, those opponents were beaten by the use of conventional warfare tactics and the application of a direct approach to military operations. This approach 
was aimed at the classic defeat of an opponent by destroying his armed forces. Western colonial powers gradually learned that such a method was only applicable to counterinsurgency operations in a limited way. Of course, European victories mostly came easy. Lightly armed and unorganised indigenous warriors were overwhelmed by Western firepower. However, often already conquered areas had to be pacified again and again. In such cases, brute force had sown the seeds for a resurgence of enemy activities. The direct approach thus was regarded as insufficient. Sometimes an answer was sought in complementary punitive measures against the local population, including livestock and crops. The 1906, British Small Wars Manual (first edition 1896) reverts to this practice:

When, however, the campaign takes the form of quelling an insurrection, the object is not only to prove to the opposing force unmistakably which is the stronger, but also to inflict punishment on those who have taken up arms. In this case it is often necessary to injure property. ... Expeditions to put down revolt are not put in motion merely to bring about a temporary cessation of hostility their purpose is to ensure lasting peace. Therefore, in choosing the objective, the overawing and not the exasperation of the enemy is the end to keep in view. ${ }^{34}$

The second part of this quote indicates that by the standards of the day, such practices were theoretically already considered as a measure of last resort. In reality, however, the use of punitive measures and brute force against native people remained an acceptable military practice until deep into the $20^{\text {th }}$ century. Yet, modern counterinsurgency took root at the end of the $19^{\text {th }}$ century. The lessons learnt from colonial campaigns led to wide acceptance of some modern counterinsurgency principles, suggesting the beginnings of universally shared doctrine. ${ }^{35}$ The main revolution occurred when Western troops started to pay attention to local support for insurgencies. The use of indigenous forces proved to be a successful tool for the undermining of the insurgents' support, as did the strategy of population resettlement. ${ }^{36}$ Thus, counterinsurgency shifted from a direct approach to an indirect approach, aimed at the local population. This, however, did not directly result in a less violent attitude towards the local population, as the use of brute force was still regarded an appropriate method. The resettlement of Boer families during the second Anglo-Boer war (1899-1902) for instance, (at that time known as reconcentration) was known to be supported by such harsh measures. It was only after the Second World War that Western soldiers started to fully comprehend the political nature of insurgencies. ${ }^{37}$ Wars of decolonisation provided new practices in 
the art of counterinsurgency. Especially the Malayan emergency (1948-1960) brought together previous experiences and new insights. Limited violence was used in combination with a programme to win the hearts and minds of the people, as the British High Commissioner General Sir Gerald Templer called it. ${ }^{38}$ This resulted in effect, as the insurgency conducted by the Malayan Communist Party was successfully defeated. Thus, with the use of knowledge from the colonial past and new experiences from after 1945, contemporary counterinsurgency theory was constructed.

The nucleus of counterinsurgency campaigns consists of five basic principles, formulated in the mid-1960s by Robert Thompson. ${ }^{39}$ As a first principle, the government must have a plain political goal: "to establish and maintain a free, independent and united country which is politically and economically stable and viable". ${ }^{40}$ The establishment of structured administrative institutions allows government to comply with the people's legitimate needs. Thus the government can outbid the insurgents for the loyalty of the people.

The second principle demands the government to act in accordance with the law. Although it can be tempting to avenge insurgent violence with brute force, the government should obey its own laws. The instrument of law thus limits the use of force. This benefits the government's cause as it averts the disastrous application of indiscriminate violence, and therefore prevents the affection of popular support by such deeds.

A third principle is the implementation of an overall plan to defeat the insurgency. Such a plan must cover all government efforts, ranging from the military and the police to socio-economic and political measures. The execution of this plan has to be coordinated by a system of civil-military cooperation bodies (from the strategic down to the tactical level).

The fourth principle is the priority of the fight against the insurgents' political subversion. By eliminating insurgent subversion activity, the support of the local people can be denied to the insurgency. This causes a chasm between the population and the insurgents. When insurgents can thus be isolated from the people, the armed forces can mount an attack to destroy these adversaries.

The fifth and last principle orders the government to establish a secure base when faced with massive insurgence attacks. Such a base can be used as a safe haven from where the counterinsurgency campaign methodically is undertaken. By 
slowly enlarging the base area outwards, the area under government control can be extended. This fifth principle also stresses the importance of patience in counterinsurgency campaigns. The government should prepare to conduct a campaign for a long haul, instead of the pursuit of quick military victories. Only an approach with a comprehensive long-term strategy will succeed in counterinsurgency.

Most contemporary scholars agree that, in addition to those five principles, the essential role of intelligence constitutes a sixth principle. ${ }^{41}$ Intelligence is of vital importance as it reveals the weak spots of an insurgency. However, as information can best be acquired from the local population, it might be difficult to access valuable intelligence. Therefore Western soldiers should submerge themselves in local society. This point was clearly brought forward by Frank Kitson when he stated that "only by so doing, will they [Western counterinsurgents] be able to see things from the point of view of the population whose allegiance they are trying to regain and retain." 42

The principles of counterinsurgency focus on the overall campaign plan of the government. This is a necessity as a successful counterinsurgency campaign contains a comprehensive government-wide approach to the problem. Military, political and socio-economic measures have to be employed to support an insurgency-threatened government. In this type of campaign, Western military forces seek to win the hearts and minds of the local people as well as to fight the insurgents with force. Counterinsurgency as a concept thus stems from or includes a certain military tradition. Even today it can be observed that the position of the military in a Western counterinsurgency campaign is paramount. Diplomats, development workers and police officers only make up a small part of the so-called comprehensive approach to counterinsurgency. This is a consequence of bureaucratic and cultural obstacles as much as a traditional lack of capacity for foreign deployments that civil agencies suffer. ${ }^{43}$ Thus, in the daily practice of Afghanistan and Iraq, Western armed forces also have to fulfil much of, for instance, the administrative and rebuilding tasks normally adhered to by other government agencies and non-governmental organisations, simply because there are not enough non-military personnel for these tasks. General Krulak introduced the concept of the three-block war to describe this phenomenon, which was also observed during the peacekeeping operations of the $1990 \mathrm{~s}:^{44}$

In one moment in time, our service members will be feeding and clothing displaced refugees-providing humanitarian assistance. In 
the next moment, they will be holding two warring tribes apartconducting peace-keeping operations. Finally, they will be fighting a highly lethal mid-intensity battle. All on the same day, all within three city blocks. It will be what we call the three-block war. ${ }^{45}$

This quote illustrates that soldiers have to execute multiple, complex tasks in contemporary operations. In counterinsurgency campaigns, they might have to assist village leaders one day and fight a fierce battle with insurgents the other day. Soldiers are engaged in all kind of activities, both "non-kinetic" (non-violent) and "kinetic" (violent) as today's soldiers phrase it. Let us now take a profound look at the consequences for military operations, which result from the principles of counterinsurgency.

The primacy of a clear political goal demands soldiers to assess all operations on their political effect. ${ }^{46}$ All actions undertaken should contribute to the host government's political objective. The military has to attain the population's support for an effective counterinsurgency campaign. Only with the assistance of the local people can insurgents be separated and defeated. Therefore it is necessary to protect the population and to provide support to the people (for example food aid, agricultural support or education). The reconstruction of administrative institutions helps the government to address the people's needs and thus acquires local support. The use of violent military methods should be limited as much as possible. If force is used it must be in strict accordance with the rule of law. The critical enabler for all those activities is intelligence. Information identifies the insurgents' cause and whereabouts as well as the local people's attitude towards the insurgency and government. Therefore any military plan to counter insurgency should be based on a profound understanding of the environment. "Know your turf" is an imperative for soldiers engaged with counterinsurgency. ${ }^{47}$ Thus, a complex military campaign, which combines these elements, is needed to overcome the protracted nature of an insurgency.

The Australian army's approach of such a campaign across five lines of operations gives us a clear example of the different roles the military has to fulfil in today's counterinsurgency operations. ${ }^{48}$ The first operational line of importance is that of joint land combat. These military actions include the creation of a stable environment to conduct the other operational lines as well as target actions against insurgent combatants. Population protection comprehends those actions that provide security to the local population. Public information includes all actions aimed at the acquirement of popular support for the government's cause. This operational line 
seeks not only to inform a targeted group of people, but also to shape their perception, attitude and behaviour. The fourth operational line consists of population support, which denotes all actions to provide the local people with the necessary aid. The final operational line is indigenous capacity building. This is made up from all activities to assist in the development of effective government institutions.

This contemporary approach to counterinsurgency indicates once more that military combat operations against insurgents fulfil an insubordinate role during counterinsurgency campaigns. Counterinsurgency is a reaction to an insurgency; it seeks to fight insurgents for the favour of the local population. Counterinsurgency is therefore all about the people. The role of the military in counterinsurgency can thus not be limited to military operations alone. Non-military means are predominant to diminish the insurgents' popular support to effect. The correct use of political and socio-economic measures as stressed by counterinsurgency theory should turn deployed soldiers into determinant actors, who are able to rally the local people's support for their cause.

\section{Western military culture and counterinsurgency: an ambiguous reality}

When studying Western military culture and counterinsurgency, the contrast between these concepts becomes obvious. Western military culture is about fighting large-scale decisive battles with armies of other states. Counterinsurgency is about outbidding the insurgents for the favour of the people. The role of force in such a campaign should be minimised. The differences in the notions that Western soldiers and insurgents hold on moral, intellectual and technological aspects of warfare, illustrate the contradistinction between the two concepts. Western soldiers pursue decisive battle; insurgents prefer to avoid battle and only fight when it suits them. Contrary to conventional armed forces, insurgents cannot be compelled to fight a battle. If faced with massive opposition, insurgents can fall back on irregular tactics, or they might even decide to do nothing.

Western military culture considers war as an activity of the state to achieve political objectives. According to this concept, the military is the primary tool to wage war. The defeat of another state's military is the main goal of war. Thus the state (government) and population, the other two elements of the Clausewitzian trinity, are not a direct subject of warfare. ${ }^{49}$ As far as the political nature of war, there is some similarity between the concepts. Insurgents also seek to reach a political objective. An insurgency, however, is not a state; it contests a state for its political control. ${ }^{50}$ An insurgency aims at weakening the state by affecting all three 
components of the Clausewitzian trinity: the state, the military, and the people. The former two are the subject of violent attention; the latter is mainly dealt with through subversion. Western armed forces rely heavily upon technology, but insurgencies are relatively low-tech. Insurgents lack complex platforms such as fighter jets and tanks. Technologically advanced Western forces seek decisive battle against other armed forces. The relatively low-tech insurgents rather avoid battle against armed forces and try to enforce decision by employing irregular warfare methods. Therefore, appropriate use of insurgent tactics, combined with the support of the people (acquired through subversion) and low-tech appearance renders Western capability to fight and win large-scale battles highly irrelevant.

Counterinsurgency theory takes this into account by emphasising a comprehensive governmental approach to counter a protracted insurgency. As already emphasised, the main effort in such a campaign is not to fight the insurgents; acquiring the people's support is paramount. Therefore the use of violence should be limited. Colonial experiences first rendered the insight of the local population as a pressure point. Thus, in order to gain the trust of the people the military should become a powerbroker within local society. Non-military means are predominant to diminish the insurgents' support to effect. Therefore, counterinsurgency demands Western soldiers to adapt. Instead of fighting large-scale battles, they have to use limited force and concentrate on non-military tasks ranging from agricultural assistance to administration. This requires armed forces "to embrace change and new ideas, and cease holding on doggedly to preconceived theories and orthodox solutions". 51

How does this occur in the realty of counterinsurgency campaigns? Throughout history Western forces have struggled with the adaptation for counterinsurgency operations. The preoccupation with large-scale decisive battle is deeply rooted in Western military culture. This trait could already be detected in the epoch of colonial warfare. The Dutch Colonial army, for example, struggled for forty years (1873-1913) to quell an insurgency in Northern Sumatra's Aceh province. Heavily influenced by the lessons of the Franco-Prussian war of 18701871 and the Russo-Turkish war of 1877-1878, the first years of the conflict were characterised by a "European" approach. A 1930 study on the Aceh conflict observes:

Without reckoning the fact that the outcomes of European warfare cannot be transferred directly to the fight against the indigenous enemy with his very specific character, great credit was 
given to the use of massive fire, especially the volley, against indigenous gangs. A very slow operational pace and complicated, unwieldy combat formations were a result of this practice. ${ }^{52}$

Due to these practices, the colonial army was unable to engage the irregulars to effect. Moreover, the massive formations, which had to deploy in the open, made up an easy target for the Acehnese marksmen. This forced the colonial army to fall back on fortified positions. The Dutch forces found themselves fixed in a stalemate with an enemy that could not be beaten effectively. Only after the adoption of new tactics (focussed on highly mobile small units) and the establishment of a new type of special forces unit, the Korps Marechaussee, in the 1890s, the campaign started to be more successful. It has to be mentioned that the work of Dutch Islam scholar Dr Christian Snouck Hurgonje, who studied Acehnese society from the inside, offered the hard-needed intelligence for the new approach. Snouck also pressed for the social and economic development of the Acehnese people, which ultimately became part of an overall campaign plan for the Acehnese war.

The British, who had extensive experiences in fighting insurgencies, were also affected by this preference for conventional warfighting skills. ${ }^{53}$ This can be illustrated by an operation in Peshawar in $1930 .^{54}$ Armoured cars were used to suppress a Muslim mob in the city streets. As one of the cars broke down in the narrow allies, the other cars, supported by infantry, used their machine gun firepower at the poorly armed rioters. This harmed the reputation of the British government and therefore rallied more support for the Muslim rebellion. The French and American experiences in South-East Asia were already mentioned. Roger Trinquier and a senior American officer in Saigon respectively provide us with an excellent insight in the uncontested dominance of conventional warfare, which prevailed in both the French and the American approach of the conflict:

From one campaign to another, our commanders tried to drive the Vietminh into a classic pitched battle, the only kind we knew how to fight, in hope that our superiority in materiel would allow an easy victory. ${ }^{55}$

I will be damned if I will permit the U.S. Army, its institutions, its doctrine, and its traditions to be destroyed just to win this lousy war. ${ }^{56}$ 
Thus, the United States went on fighting the Vietcong by using massive firepower and conventional warfighting skills or "counterinsurgency Americanstyle" as Andrew Krepinevich called it. ${ }^{57}$ The strategic defeat which resulted from this approach is well-studied by the United States military, as "writing down observations and lessons learned is a time-honored tradition of soldiers". ${ }^{5}$ The contemporary war in Iraq has shown us that soldiers might have written down these lessons, but have not learned from them. A colonel who deployed to Iraq after the completion of the 2003 invasion, discovered that his outfit was ill-fitted for the counterinsurgency campaign he found himself in:

Second BCT (Brigade Combat Team) deployed to Iraq in May 2003. We were a conventional heavy BCT, task-organised with two mechanized infantry battalions, a cavalry squadron, an armor battalion, a field artillery battalion, an engineer battalion, a support battalion, and a military police battalion. The BCT's train-up prior to deployment had focused on conventional, mid-to high-intensity combat, and our battalion and brigade headquarters and staff processes were still optimized to fight a conventional threat. ... Instead, we found ourselves in the midst of an insurgency, confronted by an elusive enemy force that wore no uniform and blended seamlessly into the local population. ${ }^{59}$

The colonel took the hard-needed measures to reorganise his unit for counterinsurgency operations. The awareness of the specific demands for counterinsurgency campaigns has considerably risen since that time as witnessed by the introduction of FM 3-24 Counterinsurgency, and the adoption of counterinsurgency policies in Iraq as well as Afghanistan. ${ }^{60}$ The reality in the field, however, reveals that the soldiers who are fighting today's campaigns are still hampered by an inability to effectively adapt to the "new" circumstances. ${ }^{61}$ In this regard, it has become clear that the various NATO countries involved in the ISAF mission in Afghanistan have experienced extensive problems in adapting to population-centric counterinsurgency. Especially the 2006 expansion of ISAF to the turbulent Southern regions of Afghanistan revealed the troublesome adaptation of NATO forces as from the outset it was reported that NATO might lose the battle for the hearts and minds in the region, thus failing to rally the support of the local population. ${ }^{62}$ The inability of Western soldiers to penetrate Afghan tribal society seemed to be the major cause of this. The military emphasised combat operations and the use of violence, thus not paying enough attention to the "non-kinetic" side of the coin. This was enhanced by the modus operandi of the Taliban. British forces in 
Helmand, for example, had to fight a four-month "break-in battle" against the Taliban in 2006. ${ }^{63}$ When their presence was finally established they again came under large-scale attacks during 2007. This forced the British forces to revert to conventional tactics and deploy massive firepower. ${ }^{64}$

The southern part of Afghanistan was even the stage for mechanised operations in order to defeat Taliban forces fighting in the conventional mode. ${ }^{65}$ An example of such an operation is the battle of Chora, which was fought by Dutch and Afghan Forces in July 2007. In addition to dismounted infantry and armoured infantry fighting vehicles, massive fire support means such as $155-\mathrm{mm}$ calibre pantserhouwitser artillery and vast air assets were committed to the task of relieving the besieged Chora district centre known as the "white compound". After a threeday fight, ISAF forces prevailed, also thanks to the help of Afghan National Security Forces and the local militia of Rosi Kahn. The collateral damage caused by the deployment of conventional firepower, however, raised questions on the methods and material used during the battle. The Dutch Ministry of Defence estimated that 50 to 80 civilians died during the fight. ${ }^{66}$ These casualties might have been caused by either Taliban activity or collateral damage. The final investigation by the Dutch prosecutor general concluded that the Dutch military were not to blame for these casualties and that the use of massive firepower was allowed within the framework provided by the rules of engagement and the laws of armed conflict. ${ }^{67}$

The Chora case demonstrates once again that adaptation to counterinsurgency operations is a troublesome undertaking for Western forces. Although the motto of the Dutch Task Force at that moment was "It's all about the Afghan people", 68 the adaptation of a population-centric counter-insurgency approach was still in process and Dutch forces (especially the battle group consisting of an infantry battalion) at that time were focussed on conventional operations. In the Chora district, the Dutch forces had no permanent presence and, therefore, they lacked a clear picture of the population and its relations with the insurgents. This allowed a build-up of Taliban forces in the Chora district, as the insurgents succeeded to merge with local society. Consequently, a conventional battle had to settle the struggle for dominance in the Chora district. It is also worth mentioning that the Dutch army mounted a large road show after the battle. This road show toured the army's barracks in order to share the experiences of the battle. The fourhour presentation focussed heavily on conventional warfighting skills; the attention given to counterinsurgency operations was almost absent. This is a void in terms of promoting conventionally styled operations while the main focus must be the essence of how to cultivate popular support. 
Of course, non-kinetic measures were coordinated with violent operations as mentioned above. Obtaining the local population's support has always been an integral part of the overall approach. The urgent necessity to counter Taliban offensives with conventional battles, however, caused a strong interference with reconstruction and humanitarian operation lines. The British House of Commons' Defence Committee acknowledges that the large number of conventional operations had alienated the population from the Afghan national government and ISAF. ${ }^{69} \mathrm{~A}$ temporary emphasis on combat might even have eroded the effort that was put into the other operation lines of a counterinsurgency campaign.

The reality of counterinsurgency is thus heavily affected by Western military culture. This results in an ambiguous reality. Western soldiers are familiar with counterinsurgency theory. When the military actually has to execute such a campaign it falls back on the well-known skills and drills of conventional warfare. ${ }^{70}$ As the two concepts are contradistinctive, this affects the Western ability to conduct an effective counterinsurgency campaign. Therefore I argue that the historic experiences, which have constructed Western military culture, offer an explanation for some of the problems experienced during contemporary counterinsurgency. Militaries influenced by this historical heritage are organisations optimised to provide the state with a capacity to wield force vis-à-vis similar opponents. The excuse for not fighting well in counterinsurgency campaigns, therefore, is, ironically, provided by this same historic dimension which, according to Lawrence, serves to exclude such an excuse.

\section{Endnotes}

${ }^{1}$ As cited in Asprey, RB. War in the shadows: The Guerrilla in history. Lincoln: iUniverse, 2005, 191.

${ }^{2}$ Smith, R. The utility of force: The art of war in the modern world. London: Penguin Books, 2005, 3-4.

${ }^{3}$ Lynn, J. Battle: A history of combat and culture from ancient Greece to modern America. Boulder, CO: Westview Press, 2003, xix.

${ }^{4}$ This is the predominant culture of Western military forces. Of course there also are some exceptions, such as most Special Forces, which have other thoughts on warfare.

${ }^{5}$ Keegan, J. A history of warfare. New York: Vintage Books, 1994, 389.

${ }^{6}$ Hanson, VD. The Western way of war: Infantry battle in Classical Greece. London: Hodder \& Stoughton, 1989, 9. 
7 This contrasted highly with primitive warfare, in which rituals emphasised peaceful solutions (including diplomatic negotiations and bribes), thus often preventing mass slaughter. In the eyes of their contemporaries, this form of combat seemed odd. Persian commander Mardonius even considered the Greeks as foolish for fighting deadly decisive battles on a smooth and fair plain. Lynn, J. Battle: A history of combat and culture from ancient Greece to modern America. Boulder, CO: Westview Press, 2003, 10.

${ }^{8}$ Keegan op. cit., p. 390.

${ }^{9}$ Among others: Lynn op. cit.; Shaw, M. The new Western way of war. Cambridge: Polity Press, 2007.

${ }^{10}$ Lynn op. cit., p. 21.

${ }^{11}$ Keegan op. cit., p. 390.

${ }^{12}$ Gray, CS. Strategy for chaos: Revolutions in military affairs and the evidence of history. London: Phoenix, 2002, 140.

13 Tugwell, M. Adapt or perish: The forms of evolution in warfare. In Charters, DA \& Tugwell, M (eds), Armies in low-intensity conflict. London: Brassey’s, $1989,6$.

${ }^{14}$ For Von Clausewitz on small wars, see, for instance, Von Clausewitz, C. On war. Princeton: Princeton University Press, 1989, 479-483.

${ }^{15}$ Smith op. cit., pp. 57-60.

${ }^{16}$ Van Creveld, M. The transformation of war. New York: Free Press, 1991, 12.

${ }^{17}$ Although it has to be admitted that at the end of the Indo-China war the Viet Minh referred to conventional tactics.

${ }^{18}$ Fall, BB. Street without joy. Mechanicsburg: Stackpole Books, 1994, 259.

${ }^{19}$ Smith op. cit., p. 206.

${ }^{20}$ Ibid., p. 152.

${ }^{21}$ Gat, A. A history of Western military thought: From the Enlightenment to the Cold War. New York:Oxford University Press, 2001, 827.

${ }^{22}$ Shaw op. cit., p. 71.

${ }^{23}$ Ibid., p. 94.

${ }^{24}$ This is illustrated by the Western tendency to pay compensation for civilian casualties caused by soldiers. The live of an Iraqi is worth approximately \$2 500 (Van Creveld, M. De evolutie van de oorlog: Van de Marne tot Irak. Utrecht: Spectrum, 2007, 305).

${ }^{25}$ Mockaitis, TR. British counterinsurgency, 1919-60. New York: St. Martin's Press, 1990, 3.

${ }^{26}$ Fall, BB. "The theory and practice of insurgency and counterinsurgency". Naval War College Review LI/1. Winter 1998. 53. 
${ }^{27}$ Rabasa, A, Lesley, AW, Chalk, P., Khilko, I., Shukla, P., Money in the bank: Lessons learned from past counterinsurgency operations. Santa Monica, CA, 2007, 60-61.

${ }^{28}$ Mockaitis op. cit., p. 5.

${ }^{29}$ A profound insight into Taliban tactics is provided by Poole, HJ. Militant tricks: Battlefield ruses of the Islamic insurgent. Emerald Isle: Posterity Press, 2005, 91-100.

${ }^{30}$ Mockaitis, TR. "From counterinsurgency to peace enforcement: New names for old games?" Small Wars and Insurgencies 10/2. 1999. 22.

${ }^{31}$ Poole, HJ. Tactics of the crescent moon: Militant Muslim combat methods. Emerald Isle: Posterity Press, 2004, 164-165.

${ }^{32}$ Gray, C. "Irregular warfare: One nature, many characters". Strategic Studies Quarterly 1/2. 2007. 48.

${ }^{33}$ Beckett, IFW (ed). The roots of counter-insurgency. London: Blandford, 1988, 6.

${ }^{34}$ Calwell, CE. Small wars: Their principles and practices (3rd ed). Lincoln: University of Nebraska Press, 1996, 41-42.

${ }^{35}$ Beckett op. cit., p. 9.

${ }^{36}$ Ibid., pp. 9-10, 14.

${ }^{37}$ It must be mentioned that insurgent ideologies also became more evident as a result of theoretical works such as those of Lawrence, Lenin and Mao.

${ }^{38}$ Stubbs, R. Hearts and minds in Guerrilla warfare: The Malayan emergency 1948-1960. Singapore: Eastern Universities Press, 2004, 1.

39 Thompson, R. Defeating communist insurgency, London: Chatto \& Windus, 1966, $50-58$.

${ }^{40}$ Ibid., pp. 50-51.

${ }^{41}$ Some examples: Brocades Zaalberg, TW. "Hearts and minds of search and destroy? Leren van klassieke counter-insurgency". Militaire Spectator 176/7-8. 2007; Mockaitis, From counterinsurgency to peace enforcement ... op. cit.

${ }^{42}$ Kitson, F. Low intensity operations: Subversion, insurgency, peace-keeping. London: Faber and Faber, 1971, 201.

${ }^{43}$ Latawski P. "Tackling counterinsurgency and post-conflict reconstruction: Recent experiences and best practices". Report on Wilton Park Conference WP829, 6-7.

${ }^{44}$ Brocades Zaalberg, TW. Soldiers and civil power: Supporting or substituting civil authorities in modern peace operations. Amsterdam: Amsterdam University Press, 2006, 14-15. 
${ }^{45}$ General Charles C. Krulak, as cited in: Cocksedge, S. "The three-block war and future conflict: Some implications for the Rifle Platoon". Australian Army Journal III/1. 2005Year. 267.

${ }^{46}$ Crane, C, Horvath, J \& Nagl, J. "Principles, imperatives and paradoxes of counterinsurgency”. Military Review March-April. 2006. 50.

${ }^{47}$ Kilcullen, D. “"Twenty-eight articles': Fundamentals of company-level counterinsurgency". Military Review May-June. 2006. 103.

48 The Australian Army. Adaptive campaigning: The Land Force response to complex warfighting, Version 4.18. Canberra, 2006, 27-28.

${ }^{49}$ In a total war, the whole trinity will be mobilised and might suffer direct attack. The allied bombings of German cities during the Second World War are an example of this. The core assumption of Western military culture, however, is that war is waged between opposing armed forces.

${ }^{50}$ It has to be mentioned that an insurgency also consists of a Clausewitzian trinity; the position of the state in the classical trinity is taken by for instance tribal leaders (Echevaria II, AJ. Fourth-generation war and other myths. Carlisle: Publisher, 2005, 7).

${ }^{51}$ Alexander, B. How wars are won: The 13 rules of war-from ancient Greece tot the War on Terror. New York: Publisher, 2002, 15.

${ }^{52}$ Struijvenberg, A. Het Korps Marechaussee op Atjeh. Koetaradja: Publisher, 1930, 6.

${ }^{53}$ Some countries had fewer difficulties adapting for counterinsurgency than others. Maintaining order in the vast colonial possessions of the empire had been the British army's main task for a long time. Thus, the specific demands for fighting insurgencies were strongly embedded in the British forces.

${ }^{54}$ Beckett op. cit., pp. 18-19, 28-29.

${ }^{55}$ Trinquier, R. Modern warfare: A French view of counterinsurgency. London: Publisher, 2006, 3. Trinquier continues to state that the Vietminh successfully eluded such battles until the moment they assembled superior resources to face the French tête à tête at Dien Bien Phu in May 1954.

${ }^{56}$ As cited in Jenkins, MB. The unchangeable war. Place of publication: RAND, $1970,3$.

${ }^{57}$ Krepinevich Jr, AF. The army and Vietnam. Baltimore, MD: Publisher, 1988, 214.

${ }^{58}$ Petraeus, DH. "Learning counterinsurgency: Observations from soldiering in Iraq". Military Review January-February. 2006. 2.

${ }^{59}$ Baker, RO. "Humint-centric operations: Developing actionable intelligence in the urban counterinsurgency environment”. Military Review March-April. 2007. 13. 
60 The US military has learned and institutionalised counterinsurgency (as a consequence of the Iraq experiences) since early 2004. This development has been closely watched and followed by many Western armed forces. See Ucko, D. "Innovation or inertia: The US Military and the learning of counterinsurgency". Orbis Spring 2008; Kitzen, MWM. “Aanpassen of aanmodderen? De Amerikaanse omschakeling naar counterinsurgency in Irak", Militaire Spectator 178/6. 2009.

${ }^{61}$ Although the Western style militaries also have difficulties in adapting to the specifics for counterinsurgency on the institutional level, I here focus on the soldiers in order to highlight the operational consequences.

${ }^{62}$ For instance: Azarbaijani-Moghaddam, S, e.a. Afghan hearts, Afghan minds: Exploring Afghan perceptions of civil-military relations. Place: Publisher, year, 77; Zroona aw Zehnoona. SENLIS Afghistan: An assessment of the Hearts and Minds Campaign in southern Afghanistan. $<$ http://www.senliscouncil.net/>, 4, Latawski, P. "Tackling counterinsurgency and post-conflict reconstruction: Recent experiences and best practices". Report on Wilton Park Conference WP829, 3.

${ }^{63}$ Bishop, P. 3 PARA. London: Publisher, 2007, 265.

${ }^{64}$ House of Commons Defence Committee. UK operations in Afghanistan.

Thirteenth Report of Session 2006-07. London, 2007, 26, 29.

${ }^{65}$ Maloney, SM. "Conceptualizing the war in Afghanistan: Perceptions from the front, 2001-2006". Small Wars and Insurgencies 18/1. March 2007. 38.

${ }^{66}$ Vrijsen, E. "Het gevecht om Chora". Elsevier January 2008. 21.

${ }^{67}$ Koelé, T. "Militairen van strijd met Taliban worden niet vervolgd". Volkskrant. 1 July 2008.

${ }^{68}$ Griensven, H. "It's all about the Afghan people: Eén jaar 1 (NLD/AUS) Task Force Uruzgan". Atlantisch Perspectief 6. 2007.

${ }^{69}$ House of Commons Defence Committee op. cit., p. 17.

${ }^{70}$ This provoked scholars such as Martin van Creveld and Edward Luttwak to state that it might be better if Western troops again adopt a more direct approach to counterinsurgency. Van Creveld, De evolutie van de oorlog ... op. cit.; Luttwak, E. "Dead end: Counterinsurgency warfare as military malpractice". Harpers' Magazine. February 2007. 